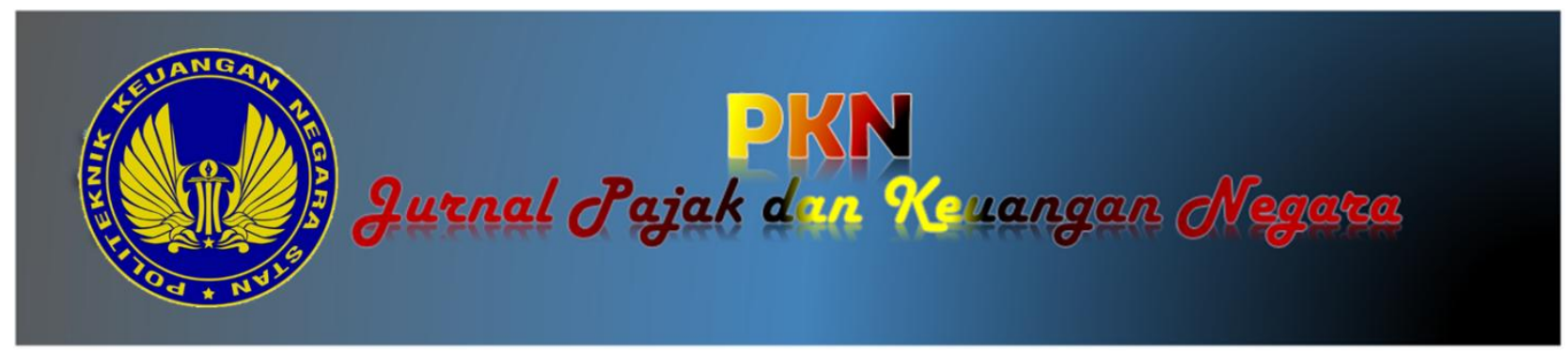

\title{
PENGARUH DANA DESA DAN KUALITAS PENYELENGGARAAN PEMERINTAHAN DAERAH TERHADAP PENDAPATAN ASLI DAERAH DI INDONESIA
}

\author{
${ }^{1}$ Pambudi Rido Priyoko \\ ${ }^{2}$ Naili Luthfi Syarifah \\ ${ }^{3}$ Dwiyan Irfan Nugraha \\ ${ }^{4}$ Bernadi Vito \\ ${ }^{1-4}$ Politeknik Keuangan Negara STAN
}

Alamat Korespondensi: ${ }^{1}$ pambudi.rido@gmail.com, ${ }^{2}$ naililuthfi@gmail.com, ${ }^{3}$ dwiyanirfan@gmail.com, 4vitobernadi@gmail.com

\section{INFORMASI ARTIKEL}

Diterima Pertama

[18 Maret 2020]

Dinyatakan Diterima

[20 Maret 2020]

KATA KUNCI:

Dana Desa, EKPPD, Pendapatan Asli Daerah.

KLASIFIKASI JEL: XX

\section{ABSTRAK}

This study aims to empirically examine the effect of Dana Desa on Regional Revenue in Indonesia. In addition, this study also examines whether the quality of implementing regional governance as measured by the EKPPD score strengthens the influence of Dana Desa on Regional Revenue. This study is tested with two models: non-lagged and lagged panel regression models. It is found that Dana Desa has a positive effect on Regional Revenue. In addition, this study also finds that the moderation in the quality of local government administration strengthens the positive influence of Dana Desa on Regional Revenue. These results indicate that the granting of Dana Desa to the Regions with good governance promotes the ability of the Regions to generate their Regional Revenue.

Penelitian ini bertujuan untuk menguji secara empiris pengaruh Dana Desa terhadap Pendapatan Asli Daerah di Indonesia. Selain itu, penelitian ini juga menguji apakah kualitas penyelenggaraan pemerintahan daerah yang diukur dengan nilai EKPPD memperkuat pengaruh Dana Desa terhadap Pendapatan Asli Daerah. Penelitian ini diuji dengan dua model yaitu non-lagged panel regression model dan lagged panel regression model. Penelitian ini menemukan bahwa Dana Desa berpengaruh positif terhadap Pendapatan Asli Daerah. Selain itu, penelitian ini juga menemukan bahwa moderasi kualitas penyelenggaraan pemerintahan daerah memperkuat pengaruh positif Dana Desa terhadap Pendapatan Asli Daerah. Hasil ini menunjukkan bahwa pemberian Dana Desa ke Daerah dengan kualitas penyelenggaraan pemerintahan yang baik mendorong kemampuan Daerah menghasilkan Pendapatan Asli Daerah mereka. 


\section{PENDAHULUAN}

\subsection{Latar Belakang}

Kesenjangan antara desa dan kota yang terjadi di Indonesia membuat masyarakat desa melakukan urbanisasi ke kota untuk memperoleh penghasilan yang lebih baik. Kurangnya aksesibilitas masyarakat desa terhadap berbagai sektor, seperti pendidikan, kesehatan, dan ekonomi menjadi salah satu penyebab rendahnya penghasilan masyarakat desa. Upaya membangun dan menggerakkan perekonomian desa diperlukan untuk mengurangi kesenjangan antara desa dan kota, serta sebagai solusi untuk mengurangi penumpukan jumlah penduduk di kota yang tidak terserap lapangan pekerjaan yang berisiko menimbulkan masalah.

Salah satu langkah terbaru yang diterapkan oleh Pemerintah dalam menanggulangi masalah tersebut adalah dengan menerapkan suatu transfer dana dari Pemerintah Pusat kepada Pemerintah Daerah yang disebut Dana Desa. Hal yang paling membedakan antara transfer Dana Desa dengan bentuk transfer antarpemerintah lainnya adalah pemberian diskresi secara penuh kepada Pemerintah Desa dalam mengelola dana transfer tersebut. Memajukan kesejahteraan umum adalah salah satu tujuan negara yang ingin dicapai oleh Pemerintah dan perwujudan dari cita-cita tersebut adalah dengan memberikan wewenang kepada Pemerintah Daerah untuk melakukan pembangunan sesuai dengan karakteristik daerah masing-masing.

Dana Desa diprioritaskan untuk pembangunan dan pemberdayaan masyarakat dengan menghasilkan sarana dan/atau prasarana yang bermanfaat bagi masyarakat seperti jalan desa, jembatan, sumur, drainase, irigasi, pemberian pelatihan dan pemasaran produk kerajinan, pengembangan usaha peternakan dan perikanan, serta pengembangan perekonomian melalui Badan Usaha Milik Desa (BUMDes). Dana Desa ditransfer kemudian dikelola secara otonom oleh pemerintah daerah dengan kualitas dan karakteristik pengelolaan keuangan yang berbeda karena masingmasing kepala daerah mempunyai visi dan misi yang berbeda. Tujuan politik kepala daerah memainkan peran yang sangat besar dalam pengelolaan perekonomian daerahnya. Melalui alokasi Dana Desa dan dukungan tata kelola pemerintah yang berkualitas, transfer Dana Desa diharapkan mampu mengurangi kesenjangan antara desa dan kota, serta mampu berperan lebih aktif mengelola penyelenggaraan pemerintahan untuk meningkatkan kemandirian daerahnya.

Melihat transfer Dana Desa sebagai kebijakan yang relatif baru dan mempertimbangkan adanya diskresi Pemerintah Daerah dalam pengelolaan Dana Desa tersebut, penelitian ini dilaksanakan untuk menganalisis pengaruh dari Dana Desa dan Kualitas Penyelenggaraan Pemerintah Daerah terhadap kemampuan daerah untuk membangun dan menggerakkan perekonomian daerah yang terwujud dalam Pendapatan Asli Daerah. Dua rumusan masalah yang akan dijawab dalam penelitian ini adalah apakah Dana Desa berpengaruh positif terhadap Pendapatan Asli Daerah dan apakah kualitas penyelenggaraan pemerintahan daerah memperkuat pengaruh positif Dana Desa terhadap Pendapatan Asli Daerah.

Berdasarkan studi literatur, penelitian yang telah dilakukan lebih banyak difokuskan pada dampak Dana Desa terhadap masing-masing desa atau kabupaten yang menerima Dana Desa. Sumaryana et al. (2018) berusaha menghubungkan dampak pengelolaan dan penggunaan Dana Desa terhadap pembangunan daerah secara keseluruhan dengan pendekatan kualitatif. Masaki (2018) meneliti secara kuantitatif hubungan antara transfer antarpemerintah dengan kemampuan menciptakan pendapatan (revenue) di Tanzania.

Dari berbagai penelitian yang telah ada, penelitian ini berusaha memberikan pandangan baru dengan menganalisis dampak Dena Desa secara keseluruhan dalam lingkup nasional melalui pendekatan kuantitatif. Penelitian ini berusaha menghubungkan dan menganalisis bagaimana kaitan antara Dana Desa dan pendapatan Pemerintah Daerah dengan mempertimbangkan kualitas penyelenggaraan pemerintahan sebagai faktor yang dianggap dapat memberikan dampak terhadap hubungan Dana Desa dan pendapatan Pemerintah Daerah. Diharapkan, penelitian ini dapat memperkaya literatur yang telah ada dan menghasilkan suatu analisis empiris terkait pengaruh Dana Desa terhadap Pendapatan Asli Pemerintah Daerah di Indonesia.

\section{KERANGKA TEORI DAN PENGEMBANGAN HIPOTESIS}

\subsection{Dana Desa}

Indonesia menganut sistem desentralisasi dalam penyelenggaraan pemerintahan daerah. Desentralisasi dapat didefinisikan sebagai penyerahan wewenang pemerintahan oleh Pemerintah Pusat kepada daerah otonom untuk mengatur dan mengurus urusan pemerintahan dalam sistem Negara Kesatuan Republik Indonesia. Penyelenggaraan urusan pemerintahan di daerah atau yang dikenal sebagai Pemerintahan Daerah adalah penyelenggaraan urusan pemerintahan oleh Pemerintah Daerah dan DPRD menurut asas otonomi dan Tugas Pembantuan dengan prinsip otonomi seluas-luasnya dalam sistem dan prinsip Negara Kesatuan Republik Indonesia sebagaimana dimaksud dalam Undang-Undang Dasar Negara Republik Indonesia Tahun 1945.

Dalam rangka mendanai pelaksanaan desentralisasi fiskal, Pemerintah Pusat melakukan transfer ke daerah sebagai bagian dari belanja negara 
berupa Dana Perimbangan, Dana Otonomi Khusus, dan Dana Transfer Lainnya. Salah satu dana transfer oleh Pemerintah Pusat dilaksanakan melalui alokasi Dana Desa. Dana Desa bersumber dari belanja Pemerintah dengan mengefektifkan program yang berbasis Desa secara merata dan berkeadilan.

Menurut Peraturan Pemerintah Nomor 60 Tahun 2014 tentang Dana Desa yang Bersumber dari Anggaran Pendapatan dan Belanja Negara sebagaimana telah diubah dengan Peraturan Pemerintah Nomor 8 Tahun 2016, Dana Desa adalah dana yang bersumber dari Anggaran Pendapatan dan Belanja Negara yang diperuntukkan bagi desa, yang ditransfer melalui Anggaran Pendapatan dan Belanja Daerah (APBD) kabupaten/kota dan digunakan untuk membiayai penyelenggaraan pemerintahan, pelaksanaan pembangunan, pembinaan kemasyarakatan, dan pemberdayaan masyarakat.

Berdasarkan Undang-Undang Nomor 6 Tahun 2014 tentang Desa, tujuan Dana Desa antara lain:

1. meningkatkan pelayanan publik di desa,

2. mengentaskan kemiskinan,

3. memajukan perekonomian desa,

4. mengatasi kesenjangan pembangunan antardesa, serta

5. memperkuat masyarakat desa sebagai subjek dari pembangunan.

Prioritas peruntukan Dana Desa berdasarkan PP No. 60 Tahun 2014 tentang Dana Desa yang Bersumber dari APBN sebagaimana telah diubah dengan PP No. 8 Tahun 2016 adalah untuk membiayai pembangunan dan pemberdayaan masyarakat desa.

Alokasi Dana Desa merupakan salah satu sumber Pendapatan Desa sebagai bagian dari dana perimbangan yang diterima kabupaten/kota. Pasal 5 Peraturan Pemerintah No. 60 Tahun 2014 tentang Dana Desa mengatur bahwa Dana Desa dialokasikan berdasarkan jumlah desa dan dialokasikan dengan memperhatikan jumlah penduduk, angka kemiskinan, luas wilayah, dan tingkat kesulitan geografis. Pemerintah menganggarkan Dana Desa setiap tahun dalam APBN secara nasional dan ditransfer melalui APBD kabupaten/kota untuk selanjutnya ditransfer ke APB Desa.

Berdasarkan Laporan Realisasi APBN, Transfer Dana Desa dari Pemerintah Pusat ke Daerah terus mengalami peningkatan dari tahun ke tahun. Total realisasi transfer Dana Desa naik dari sebesar Rp20.766.200.000.000 di tahun anggaran 2015 menjadi sebesar Rp46.679.329.179.366 dan Rp59.766.577.527.403 di tahun anggaran 2016 dan 2017.

\subsection{Pendapatan Asli Daerah}

Dalam penyelenggaraan pemerintahan berdasarkan sistem desentralisasi, pemerintahan daerah memiliki rencana keuangan tahunan yang tertuang dalam APBD dan di dalamnya terdiri dari pospos Penerimaan Daerah, Pengeluaran Daerah, Pendapatan Daerah, Belanja Daerah, dan Pembiayaan. Penerimaan Daerah dalam pelaksanaan Desentralisasi terdiri atas Pendapatan Daerah dan Pembiayaan. Pendapatan Daerah bersumber dari Pendapatan Asli Daerah, Dana Perimbangan, dan Lain-lain Pendapatan, sedangkan Pembiayaan bersumber dari sisa lebih perhitungan anggaran Daerah, penerimaan Pinjaman Daerah, Dana Cadangan Daerah, dan hasil penjualan kekayaan Daerah yang dipisahkan.

Pendapatan Asli Daerah (PAD) berdasarkan Undang-Undang Nomor 33 Tahun 2004 tentang Perimbangan Keuangan Antara Pusat dan Daerah Pasal 1 angka 18 adalah "... pendapatan yang diperoleh daerah yang dipungut berdasarkan peraturan daerah sesuai dengan peraturan perundang-undangan". PAD merupakan Pendapatan Daerah yang bersumber dari hasil Pajak Daerah, hasil Retribusi Daerah, hasil pengelolaan kekayaan Daerah yang dipisahkan, dan Lain-lain Pendapatan Asli Daerah yang sah, yang bertujuan untuk memberikan keleluasaan kepada daerah dalam menggali pendanaan dalam pelaksanaan otonomi daerah sebagai perwujudan asas Desentralisasi. Lain-lain PAD yang sah sebagaimana dimaksud meliputi: hasil penjualan kekayaan daerah yang tidak dipisahkan; jasa giro; pendapatan bunga; keuntungan selisih nilai tukar rupiah terhadap mata uang asing; dan komisi, potongan, ataupun bentuk lain sebagai akibat dari penjualan dan/atau pengadaan barang dan/atau jasa oleh Daerah. PAD bertujuan memberikan kewenangan kepada Pemerintah Daerah untuk mendanai pelaksanaan otonomi daerah sesuai dengan potensi Daerah sebagai perwujudan Desentralisasi.

\subsection{Kualitas Penyelenggaraan Pemerintahan Daerah di Indonesia}

Berdasarkan PP No. 6 Tahun 2008 tentang Pedoman Evaluasi Penyelenggaraan Pemerintahan Daerah, setiap tahun Pemerintah melakukan penilaian kinerja penyelenggaraan pemerintahan daerah dalam upaya peningkatan kinerja berdasarkan prinsip tata kepemerintahan yang baik. Penilaian tersebut dilakukan melalui mekanisme Evaluasi Penyelenggaraan Pemerintahan Daerah (EPPD). EPPD adalah suatu proses pengumpulan dan analisis data secara sistematis terhadap kinerja penyelenggaraan pemerintahan daerah, kemampuan penyelenggaraan otonomi daerah, dan kelengkapan aspek-aspek penyelenggaraan pemerintahan pada daerah yang baru dibentuk. EPPD dilaksanakan berdasarkan asas spesifik, objektif, berkesinambungan, terukur, dapat diperbandingkan, dan dapat dipertanggungjawabkan.

Salah satu mekanisme dalam EPPD yang dilakukan untuk menilai kinerja penyelenggaraan pemerintahan daerah adalah melalui Evaluasi Kinerja 
Penyelenggaraan Pemerintahan Daerah (EKPPD). EKPPD merupakan suatu proses pengumpulan dan analisis data secara sistematis terhadap kinerja penyelenggaraan pemerintahan daerah dengan menggunakan sistem pengukuran kinerja. Melalui sistem pengukuran kinerja yang ditetapkan, Pemerintah mengukur, menilai, dan membandingkan secara sistematis dan berkesinambungan terhadap kinerja penyelenggaraan pemerintahan daerah.

Sumber utama informasi EKPPD adalah Laporan Penyelenggaraan Pemerintahan Daerah (LPPD) selama satu tahun yang disusun berdasarkan Rencana Kerja Pembangunan Daerah dan disampaikan oleh Kepala Daerah kepada Pemerintah. Selain itu, EKPPD didukung oleh sumber informasi pelengkap seperti laporan pertanggungjawaban pelaksanaan APBD, informasi keuangan daerah, laporan kinerja instansi pemerintah daerah, dan laporan lain terkait penyelenggaraan pemerintahan daerah. Sumbersumber tersebut difokuskan pada informasi capaian kinerja pada tataran pengambil kebijakan dan pelaksana kebijakan dengan menggunakan Indeks Kinerja Kunci (IKK) keberhasilan penyelenggaraan urusan pemerintahan. Beberapa aspek pada tataran pengambilan kebijakan meliputi aspek transparansi dalam pemanfaatan alokasi, pencairan dan penyerapan Dana Alokasi Umum, Dana Alokasi Khusus, dan Dana Bagi Hasil, serta intensitas, efektivitas, dan transparansi pemungutan sumbersumber pendapatan asli daerah dan pinjaman/obligasi daerah. Aspek pada tataran pelaksanaan kebijakan meliputi perencanaan pembangunan daerah dan pengelolaan keuangan daerah. Hasil dari EKPPD diurutkan secara nasional dan dituangkan dalam Keputusan Menteri Dalam Negeri tentang penetapan peringkat dan status kinerja penyelenggaraan pemerintahan daerah secara nasional.

\subsection{Penelitian Terdahulu yang Relevan}

Penelitian terdahulu lebih banyak memberikan penekanan pada implikasi alokasi Dana Desa dalam cakupan tertentu, misalnya untuk suatu desa, kabupaten, atau provinsi tertentu penerima Dana Desa. Penelitian Azwardi dan Sukanto (2014) mencoba melihat efektivitas penganggaran Dana Desa dan menghubungkannya dengan masalah kemiskinan di Provinsi Sumatera Selatan, sedangkan Hariyanto dan Mutiarin (2016) meneliti pengaruh kebijakan Dana Desa di Kabupaten Bulungan. Penelitian yang dilakukan oleh Sumaryana et al. (2018) menganalisis dampak pengelolaan dan penggunaan Dana Desa terhadap pembangunan daerah dengan pendekatan kualitatif. Hasil penelitian menunjukkan bahwa pengelolaan dan penggunaan Dana Desa tidak memberi dampak signifikan bagi pertumbuhan pembangunan daerah, serta ada ketidakseimbangan antara program pembangunan desa dengan kebijakan pembangunan daerah (RPJM Daerah). Kuang (2019) menambahkan bahwa Dana Desa tidak memberikan pengaruh yang signifikan dikarenakan rendahnya tingkat partisipasi masyarakat, kompetensi sumber daya manusia yang kurang mumpuni, dan keterbatasan modal untuk pengembangan usaha. Keterbatasan yang dihadapi oleh desa dapat diberikan solusi oleh pemerintah daerah dengan memberikan sosialisasi dana desa dan kursus manajemen untuk pengurus desa. Masaki (2018) melakukan penelitian dengan pendekatan kuantitatif untuk menguji hubungan antara transfer antar pemerintah dengan kemampuan menciptakan pendapatan (revenue) di Tanzania. Hasil dari penelitian menunjukkan bahwa transfer antarpemerintah memberikan pengaruh positif terhadap pendapatan daerah, khususnya di wilayah pedesaan. Penelitian oleh Hamid (2013) menyatakan bahwa tata kelola yang baik mendorong pengelolaan keuangan yang efektif. Dalam hal ini, terdapat hubungan positif antara tata kelola dengan pengelolaan keuangan. Penelitian ini berusaha memberikan pandangan baru dengan menganalisis dampak Dena Desa secara keseluruhan melalui pendekatan kuantitatif dengan mempertimbangkan kualitas penyelenggaraan pemerintahan sebagai faktor yang dianggap dapat memberikan dampak terhadap hubungan Dana Desa dan pendapatan Pemerintah Daerah.

\subsection{Perumusan Hipotesis}

Sasana (2009) melakukan penelitian tentang peran desentralisasi fiskal terhadap laju pertumbuhan ekonomi. Berdasarkan penelitiannya, Sasana menyatakan bahwa desentralisasi fiskal berpengaruh secara signifikan dan positif terhadap pertumbuhan ekonomi daerah Kabupaten/kota di Jawa Tengah. Hal ini menunjukkan bahwa adanya korelasi antara desentralisasi fiskal dengan perekonomian, di mana desentralisasi fiskal diwujudkan salah satunya dalam bentuk transfer dana antar pemerintah.

Dalam capital investment yang dilakukan oleh suatu perusahaan, jumlah uang yang diperoleh perusahaan untuk mencapai tujuannya, pada umumnya dimanfaatkan untuk meningkatkan kapasitas operasional, menangkap pangsa pasar yang lebih besar, dan menghasilkan lebih banyak pendapatan (Titman, Keown, \& Martin, 2014). Adanya penambahan uang yang diterima, seharusnya mampu menghasilkan penambahan pendapatan. Pendekatan ini dapat dianalogikan dengan kondisi pemerintah daerah, di mana pemerintah daerah yang memiliki sejumlah dana dalam bentuk Dana Desa seharusnya dapat memanfaatkan dana tersebut untuk meningkatkan kapasitas daerahnya yang pada akhirnya dapat menghasilkan lebih banyak pendapatan bagi daerah tersebut. 
Penelitian Masaki (2018) menunjukkan adanya hubungan antara jumlah dana yang diperoleh suatu pemerintah daerah dalam bentuk intergovernmental transfers dengan local revenue generation. Penelitian Masaki terhadap pemerintahan Tanzania tersebut menyimpulkan bahwa dana transfer dapat meningkatkan Pendapatan Asli Daerah di Tanzania.

Berdasarkan uraian di atas, peneliti menyimpulkan hipotesis pertama yaitu:

$\mathrm{H}_{1}$ : Dana Desa berpengaruh positif terhadap Pendapatan Asli Daerah di Indonesia.

Menurut Merriam Webster dan Oxford English Dictionary, kata empower mengandung dua pengertian yaitu to give power dan to give ability. To give power berarti memberi kekuasaan, mengalihkan kekuatan atau mendelegasikan kekuatan tersebut ke pihak lain dari kondisi sebelumnya yang powerless sehingga menjadi lebih baik. To give ability atau enable berarti usaha untuk memberi kemampuan untuk melakukan sesuatu.

Karl Marx (1969) menyatakan bahwa pemberdayaan masyarakat adalah proses perjuangan kaum powerless untuk memperoleh surplus value sebagai hak normatifnya. Perjuangan untuk memperoleh surplus value dilakukan melalui distribusi penguasaan faktor-faktor produksi dan harus melalui perjuangan politik. Friedmann (1992) mengungkapkan pemberdayaan dimulai dari lingkup rumah tangga, dengan mencakup aspek sosial, politik, dan psikologis. Pemberdayaan sosial adalah usaha bagaimana rumah tangga lemah memperoleh akses informasi, akses pengetahuan dan keterampilan, akses untuk berpartisipasi dalam organisasi sosial, dan akses ke sumber-sumber keuangan. Pemberdayaan politik adalah usaha bagaimana rumah tangga yang lemah memiliki akses dalam proses pengambilan keputusan publik yang mempengaruhi masa depan mereka. Pemberdayaan psikologis adalah usaha bagaimana membangun kepercayaan diri rumah tangga yang lemah. Kehadiran Dana Desa diharapkan dapat memberdayakan masyarakat desa untuk menghasilkan surplus value dengan cara pemenuhan aspek sosial melalui kemudahan masyarakat memperoleh akses sumber-sumber keuangan, aspek politik dengan memberikan kebebasan kepada masyarakat desa dalam menentukan keputusan publik yang mempengaruhi masa depan mereka, serta aspek psikologis dengan memberikan motivasi bahwa adanya Dana Desa dapat memberikan surplus value bagi masyarakat.

Hamid (2013) menyatakan bahwa "Good governance promotes effective financial management". Berdasarkan penelitian tersebut, disimpulkan bahwa tata kelola yang baik akan berdampak pada pengelolaan keuangan yang baik pula. Penulis ingin memperkuat hasil penelitian Hamid (2013) terkait hubungan positif antara good governance dengan pengelolaan keuangan, yang diimplementasikan sebagai moderasi dari variabelvariabel pada hipotesis sebelumnya.

Berdasarkan uraian di atas, penulis menyimpulkan hipotesis kedua yaitu:

$\mathbf{H}_{2}$ : Kualitas penyelenggaraan Pemerintahan Daerah akan memperkuat pengaruh positif Dana Desa terhadap Pendapatan Asli Daerah.

Berdasarkan perumusan masalah, tujuan penelitian, serta pembangunan hipotesis yang telah diuraikan sebelumnya, kerangka konseptual dapat dibuat secara skematis sebagaimana Gambar 1.

Gambar 1

Kerangka Konseptual

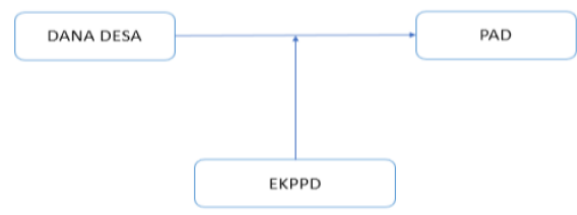

Sumber: Diolah Penulis

Keterangan:

PAD : Realisasi PAD per kabupaten/kota.

EKPPD : Hasil penilaian evaluasi kinerja yang tertuang dalam EKPPD sesuai keputusan Menteri Dalam Negeri per Kabupaten/kota.

DanaDesa : Alokasi Dana Desa per kabupaten/kota.

Berdasarkan kerangka konseptual pada Gambar 1, Dana Desa diharapkan dapat meningkatkan Pendapatan Asli Daerah. Kualitas penyelenggaraan Pemerintahan Daerah yang baik diharapkan berdampak pada pengelolaan keuangan daerah dan kualitas pengelolaan Dana Desa yang baik pula sehingga mampu meningkatkan Pendapatan Asli Daerah.

\section{METODE PENELITIAN}

\subsection{Model Penelitian}

Penelitian ini menggunakan 2 model, yaitu NonLagged Panel Regression Model dan Lagged Panel Regression Model. Masaki (2018) menggunakan model dinamis dengan anggapan bahwa local revenue yang diperoleh pemerintah daerah juga dipengaruhi oleh transfer antarpemerintah yang diperoleh di masa lalu, sehingga dapat menangkap lagged effects dari transfer antarpemerintah tersebut. Dalam penilitian ini, baik non-lagged model maupun lagged model digunakan untuk melihat apakah Pendapatan Asli Daerah dipengaruhi oleh Dana Desa yang diperoleh di tahun yang sama, ataupun dari Dana Desa yang telah diperoleh sebelumnya. Pengujian Hipotesis $H_{1}$ menggunakan model persamaan regresi sebagai berikut.

1) Non-lagged Panel

$\mathrm{PAD}_{\text {it }}=\beta_{0}+\beta_{1}$ DanaDesa $_{i t}+\beta_{2}$ Penduduk $_{\mathrm{it}}+$ $\beta_{3}$ LuasWilayah $_{\text {it }}+\varepsilon_{\text {it }}$ 
2) Lagged Panel

PADLag $_{\text {it }}=\beta_{0}+\beta_{1}$ DanaDesait-1 $+\beta_{2}$ Penduduk $_{\mathrm{it}-1}+$ $\beta_{3}$ LuasWilayah $_{\text {it }-1}+\varepsilon_{\text {it }-1}$

Keterangan:

PAD $\quad=$ Pendapatan Asli Daerah

PADLag = Pendapatan Asli Daerah (Lagged Model)

DanaDesa = Dana Desa

Penduduk = Jumlah Penduduk

LuasWilayah = LuasWilayah

$\mathrm{i} \quad=$ Kabupaten/Kota ke-i

$\mathrm{t}=$ Tahun ke-t

$\varepsilon \quad=$ residual

Hipotesis pada $\mathrm{H}_{2}$ diuji dengan persamaan regresi sebagai berikut.

3) Non-lagged Panel

PAD it $=\beta_{0}+\beta_{1}$ DanaDesait $+\beta_{2}$ EKPPD $_{\text {it }}+$ $\beta_{3}($ EKPPD $\times$ DanaDesa) it + $\beta_{4}$ Penduduk $_{i t}+\beta_{5}$ LuasWilayah $_{\text {it }}+\varepsilon_{\text {it }}$

4) Lagged Panel

PADLagit $=\beta_{0}+\beta_{1}$ DanaDesait-1 $+\beta_{2}$ EKPPD $_{\text {it- } 1}+$ $\beta_{3}$ (EKPPD $\times \quad$ DanaDesa) $)_{\text {it-1 }}+$ $\beta_{4}$ Pendudukit-1 $+\beta_{5}$ LuasWilayahit-1 + $\varepsilon_{\text {it-1 }}$

Keterangan:

$\begin{array}{lll}\text { PAD } & \text { Pendapatan Asli Daerah } \\ \text { PADLag } & = & \text { Pendapatan Asli Daerah (Lagged } \\ & & \text { Model) } \\ \text { DanaDesa } & \text { Dana Desa } \\ \text { EKPPD } & \text { Nilai Evaluasi Rinerja } \\ & \text { Penyelenggaraan Pemerintahan } \\ & \text { Daerah } \\ \text { EKPPD x DanaDesa = } & \text { Moderasi EKPPD terhadap Dana } \\ & \text { Desa } \\ \text { Penduduk } & =\text { Jumlah Penduduk } \\ \text { LuasWilayah }= & \text { Luas Wilayah } \\ \mathrm{i} & = & \text { Kabupaten/Kota ke-i } \\ \mathrm{t} & = & \text { Tahun ke-t } \\ \varepsilon & = & \text { residual }\end{array}$

Definisi operasional dari variabel-variabel dalam penelitian ini dijelaskan pada tabel 1.

Tabel 1

Definisi Operasional Variabel

\begin{tabular}{|c|c|c|}
\hline No. & Variabel & Uraian \\
\hline 1 & $\begin{array}{l}\text { Pendapatan Asli } \\
\text { Daerah (PAD) }\end{array}$ & $\begin{array}{l}\text { Variabel ini digunakan } \\
\text { pada model persamaan } \\
\text { non-lagged panel } \\
\text { regression menggunakan } \\
\text { nilai nominal Pendapatan }\end{array}$ \\
\hline
\end{tabular}

Asli Daerah per Kabupaten/kota tahun 2015 dan 2016.

2 Pendapatan Asli Variabel ini digunakan Daerah (PADLag) pada model persamaan lagged panel regression dengan menggunakan nilai nominal Pendapatan Asli Daerah per kabupaten/kota tahun 2016 dan 2017.

3 Dana Desa Variabel ini merupakan (DanaDesa) variabel independen yang menggunakan nilai nominal Dana Desa per kabupaten/kota tahun 2015 dan 2016

4 Nilai Evaluasi Variabel ini Kinerja menggunakan nilai Penyelenggaraan Evaluasi

\section{Pemerintahan Penyelenggaraan}

Daerah (EKPPD) Pemerintahan Daerah (EKPPD) kabupaten/kota tahun 2015 dan 2016. Nilai EKPPD merupakan hasil dari penilaian kinerja penyelenggaraan pemerintahan daerah dalam satu tahun oleh Kementerian Dalam Negeri.

5 Moderasi EKPPD Variabel ini merupakan terhadap Dana variabel moderasi untuk Desa (EKPPD $x$ menguji hipotesis $\mathrm{H}_{2}$ dan DanaDesa)

diukur dengan mengalikan nilai dua variabel:

EKPPD $\times$ DanaDesa $=$ EKPPD x DanaDesa.

6 Jumlah

Penduduk (Penduduk)
Variabel ini merupakan variabel kontrol dengan menggunakan nilai jumlah proyeksi penduduk kabupaten/kota tahun 2015 dan 2016 yang dikeluarkan baik oleh Badan Pusat Statistik maupun Badan Pusat Statistik Provinsi. 
7 Luas Wilayah Variabel ini merupakan (LuasWilayah) variabel kontrol yang menggunakan nilai luas wilayah kabupaten/kota tahun 2015 dan 2016.

\subsection{Data dan Sampel}

Data yang dianalisis pada penelitian ini adalah data sekunder yang diperoleh dari publikasi Kementerian Keuangan, Kementerian Dalam Negeri, dan Badan Pusat Statistik (BPS). Periode penelitian ini meliputi periode tahun 2015 sampai dengan tahun 2017. Untuk model penelitian non-lagged panel regression, periode penelitian adalah periode 2015 dan 2016. Lagged panel regression model menggunakan data panel variabel independen dan variabel kontrol tahun 2015 dan 2016 untuk dianalisis pengaruhnya terhadap variabel dependen pada tahun selanjutnya yaitu tahun 2016 dan 2017. Tahun 2015 dipilih sebagai awal periode penelitian karena alokasi Dana Desa dimulai pada tahun 2015. Periode penelitian untuk non-lagged regression model dilakukan sampai dengan tahun 2016 karena keterbatasan data EKPPD tahun 2017 yang belum dipublikasikan oleh Kementerian Dalam Negeri.

Populasi pada penelitian ini adalah kabupaten/kota di Indonesia. Pemilihan sampel pada penelitian ini dilakukan dengan menyeleksi kelengkapan data dan menggunakan metode purposive sampling berdasarkan kriteria sebagai berikut.

a. Kabupaten/kota menerima alokasi Dana Desa pada tahun 2015 dan tahun 2016.

b. Nilai EKPPD Kabupaten/Kota tahun 2015 dan 2016 ditampilkan pada publikasi Keputusan Menteri Dalam Negeri.

Berdasarkan prosedur pemilihan sampel yang dijelaskan pada tabel 2, penelitian ini menggunakan 801 sampel dari jumlah populasi sebesar 1032.

Tabel 2

Prosedur Pemilihan Sampel Penelitian

\begin{tabular}{l} 
Keterangan \\
\hline Jumlah kabupaten/kota di \\
Indonesia pada tahun 2015 dan \\
2016 (data panel) \\
Dikurangi: \\
Kabupaten/kota yang tidak \\
tersedia data Pendapatan Asli \\
Daerahnya pada publikasi realisasi \\
APBD laman Direktorat Jenderal \\
Perimbangan Keuangan, \\
Kementerian Keuangan
\end{tabular}

Jumlah

1032
Kabupaten/kota yang tidak

memperoleh Dana Desa

Kabupaten/kota yang tidak

ditampilkan/tidak tersedia data nilai EKPPD-nya

Kabupaten/kota yang tidak tersedia data jumlah penduduknya pada publikasi Badan Pusat Statistik dan Badan Pusat Statistik Provinsi

\section{HASIL PENELITIAN}

\subsection{Statistik Deskriptif}

Tabel 3 menunjukkan statistik deskriptif dari 801 sampel penelitian. Rata-rata Pendapatan Asli Daerah tahun 2016-2017 yang digambarkan oleh variabel PADLag adalah \pm Rp186 miliar, lebih tinggi dibandingkan dengan rata-rata Pendapatan Asli Daerah tahun 2015-2016 yang ditunjukkan oleh variabel PAD sebesar \pm Rp153 miliar. Rata-rata Dana Desa yang ditransfer ke Daerah selama tahun 20152016 adalah \pm Rp67,2 juta dengan jumlah Dana Desa tertinggi sebesar \pm Rp499 juta dan terendah sebesar \pm Rp547.544. Nilai EKPPD sebagai pengukur kualitas penyelenggaraan pemerintahan daerah mempunyai nilai rata-rata sebesar 2,849657, sedangkan luas wilayah dan jumlah penduduk daerah mempunyai rata-rata masing-masing 4.468,825 km2 dan 491.191,3 jiwa. Rata-rata nilai untuk variabel moderasi (EKPPD $\mathrm{x}$ DanaDesa) untuk menguji hipotesis $\mathrm{H}_{2}$ mempunyai rata-rata sebesar \pm Rp196 juta.

Tabel 3

Statistik Deskriptif

\begin{tabular}{|c|c|c|c|c|c|}
\hline Variabel & Mean & Median & Min & Max & $\begin{array}{l}\text { Std. } \\
\text { Deviasi }\end{array}$ \\
\hline PAD & $1.53 \mathrm{E}+11$ & $7.61 \mathrm{E}+10$ & $3.45 \mathrm{E}+09$ & $3.56 \mathrm{E}+12$ & $2.73 E+11$ \\
\hline PADLag & $1.86 \mathrm{E}+11$ & $9.70 \mathrm{E}+10$ & $1.97 \mathrm{E}+09$ & $4.17 \mathrm{E}+12$ & $3.27 \mathrm{E}+11$ \\
\hline DanaDesa & $6.72 \mathrm{E}+07$ & $4.32 E+07$ & 547544 & $4.99 E+08$ & $6.83 E+07$ \\
\hline EKPPD & 2.849657 & 2.9357 & 0.6237 & 3.5926 & 0.4535723 \\
\hline LuasWilayah & 4468.825 & 2369 & 61.36 & 44071 & 6011.768 \\
\hline Penduduk & 491191.3 & 273510 & 13615 & 5678600 & 601480.7 \\
\hline $\begin{array}{l}\text { EKPPD } \quad x \\
\text { DanaDesa }\end{array}$ & $1.96 \mathrm{E}+08$ & $1.23 E+08$ & 1438070 & $1.38 \mathrm{E}+09$ & $2.05 E+08$ \\
\hline $\mathrm{n}$ & 801 & & & & \\
\hline
\end{tabular}


Berdasarkan statistik deskriptif di atas, dilakukan winsorize pada data sampel penelitian untuk menghilangkan efek outlier dari data. Data winsorizing merupakan proses statistik dengan membatasi nilai ekstrim dalam data statistik untuk mengurangi efek outlier dalam pembentukan model. Pengujian hipotesis akan dilakukan dengan memasukkan data yang telah di-winsorized ke dalam model regresi.

\subsection{Uji Asumsi Regresi}

Uji asumsi regresi pada penelitian ini diawali dengan melakukan uji multikolinearitas untuk masingmasing model regresi. Hasil uji multikolinearitas ditampilkan pada Tabel 4. Dari Tabel 4 dapat diketahui bahwa nilai Variance Inflation Factor (VIF) adalah lebih kecil dari 10 untuk setiap variabel dalam model 1 dan model 2, tetapi lebih besar dari 10 pada model 3 dan model 4 untuk variabel Dana Desa, EKPPD, dan variabel moderasi (EKPPD x Dana Desa). Meskipun demikian, multikolinearitas dalam model moderasi seperti model 3 dan model 4 merupakan hal yang tidak terelakkan akibat adanya variabel moderasi, sehingga analisis untuk model moderasi tetap dapat dilakukan meskipun VIF lebih besar dari 10.

Tabel 4

Hasil Uji Multikolinearitas

\begin{tabular}{llllllllll}
\hline \multirow{2}{*}{ Variabel } & \multicolumn{2}{c}{ Model 1 } & \multicolumn{2}{c}{ Model 2 } & \multicolumn{2}{c}{ Model 3 } & \multicolumn{2}{c}{ Model 4 } \\
\cline { 2 - 9 } & \multicolumn{2}{c}{ VIF } & 1/NIF & VIF & 1/VIF & VIF & 1/VIF & VIF & 1/VIF \\
\hline Intersep & 4.95 & 0.201855 & 4.95 & 0.201855 & 152.51 & 0.006557 & 152.51 & 0.006557
\end{tabular}

$\begin{array}{lllllllll}\text { Dana Desa } & 2.63 & 0.379971 & 2.63 & 0.379971 & 97.65 & 0.010241 & 97.65 & 0.010241\end{array}$

$\begin{array}{lllllllll}\text { Penduduk } & 3.04 & 0.329421 & 3.04 & 0.329421 & 4.16 & 0.240219 & 4.16 & 0.240219\end{array}$

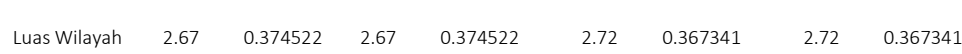

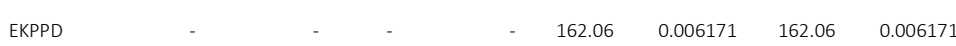

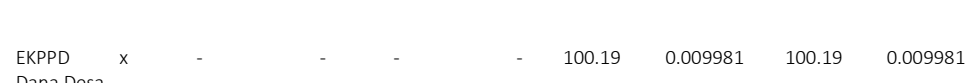

Dana Desa

\begin{tabular}{lllll}
\hline Rata-Rata VIF & 3.32 & 3.32 & 86.55 & 86.55
\end{tabular}

Uji autokorelasi dan heteroskedastisitas juga dilakukan dalam penelitian ini. Uji autokorelasi adalah sebuah uji untuk mengetahui adanya korelasi terkait waktu antar variabel gangguan sehingga penaksir tidak lagi efisien, sedangkan uji heteroskedastisitas dilakukan untuk menguji apakah terjadi gangguan yang muncul dalam fungsi regresi yang mempunyai varian yang tidak seragam. Interpretasi terhadap model dilakukan setelah uji-uji di atas dilakukan.

\subsection{Pemilihan Metode Analisis}

Penelitian menggunakan data panel yang merupakan gabungan dari data cross section sejumlah kabupaten/kota di Indonesia pada periode tahun 2015 sampai tahun 2017. Terdapat tiga pilihan metode yang dapat digunakan dalam melakukan regresi model pada penelitian ini yaitu pooled least square, fixed effect model, dan random effect model. Dalam rangka memilih pendekatan untuk tiap-tiap model, dilakukan berbagai pengujian, yaitu uji Chow (dalam rangka memilih antara pooled least square dan fixed effect), uji Breusch and Pagan Lagrangian Multiplier (dalam rangka memilih antara pooled least square dan random effect), dan uji Hausman (dalam rangka memilih antara fixed effect dan random effect). Berdasarkan uji kelayakan model yang telah dilakukan, metode yang dipilih untuk meregresi model 1 adalah random effect model sedangkan untuk model 2 , model 3 , dan model 4 adalah fixed effect model.

\subsection{Pengujian Hipotesis}

Analisis regresi data panel digunakan dalam melakukan pengujian hipotesis. Pengujian hipotesis $\mathrm{H}_{1}$ menggunakan metode random effect untuk model 1 (non-lag panel) dan fixed effect untuk model 2 (lagged panel). Pengujian hipotesis $\mathrm{H}_{2}$ menggunakan metode fixed effect baik untuk model 3 (non-lagged panel) maupun model 4 (lagged panel).

Hipotesis $\mathrm{H}_{1}$ pada penelitian ini menyatakan bahwa Dana Desa berpengaruh positif terhadap Pendapatan Asli Daerah di Indonesia. Hasil pengujian Hipotesis $\mathrm{H}_{1}$ disajikan pada Tabel 5. Pada Tabel 5 ditunjukkan bahwa baik menggunakan PAD maupun PADLag, Dana Desa signifikan dengan nilai probabilitas lebih besar dari $\alpha$ yaitu 0,05. Koefisien Dana Desa juga bertanda positif yang menunjukkan hubungan positif Dana Desa terhadap Pendapatan Asli Daerah. Temuan ini mengindikasikan bahwa Dana Desa berpengaruh positif terhadap Pendapatan Asli Daerah sehingga dapat disimpulkan bahwa Hipotesis $\mathrm{H}_{1}$ pada penelitian ini terbukti dan diterima.

Tabel 5

Hasil Pengujian Hipotesis $\mathrm{H}_{1}$

\begin{tabular}{|c|c|c|c|c|c|c|}
\hline \multirow{2}{*}{ Variabel } & \multicolumn{3}{|c|}{$\begin{array}{c}\text { Model } 1 \\
\text { Variabel Dependen: PAD }\end{array}$} & \multicolumn{3}{|c|}{$\begin{array}{c}\text { Model } 2 \\
\text { Variabel Dependen: PALlag }\end{array}$} \\
\hline & Coef. & z & Prob. & Coef. & t-stat & Prob. \\
\hline DanaDesa & 1098834 & 9,26 & 0,000 & 330,1162 & 9,94 & 0,000 \\
\hline Penduduk & 224527,7 & 31,79 & 0,000 & 3118282 & 4,61 & 0,000 \\
\hline LuasWilayah & -1142701 & $-1,36$ & 0,174 & $-1,66 \mathrm{E}+07$ & $-2,12$ & 0,035 \\
\hline Intersep & $1,86 \mathrm{E}+10$ & 3,5 & 0,000 & $-1,14 \mathrm{E}+12$ & $-4,08$ & 0,000 \\
\hline & R squared & 0,7321 & & R squared & 0,7356 & \\
\hline & Wald chi2 (3) & 1291,98 & & F-Stat & 124,53 & \\
\hline & Prob > chi 2 & 0,0000 & & Prob $>F$ & 0,0000 & \\
\hline
\end{tabular}

Pengaruh positif Dana Desa terhadap Pendapatan Asli Daerah terjadi pada tahun 
ditransfernya Dana Desa seperti dibuktikan pada hasil regresi model 1 maupun tahun setelahnya yang ditunjukkan pada hasil regresi model 2. Dengan demikian, Dana Desa yang diberikan ke desa-desa di daerah mampu memberi dampak terhadap Pendapatan Asli Daerah di suatu daerah baik pada tahun Dana Desa diterima, maupun untuk tahun selanjutnya. Hal ini dimungkinkan karena penggunaan Dana Desa tidaklah terbatas pada hal-hal yang bersifat konsumsi habis tahun, tetapi juga untuk hal-hal yang mempunyai dampak multi tahun, misalnya pembangunan infrastruktur, seperti jalan, bangunan, dan saluran irigasi. Oleh karena itu, Dana Desa dapat memberi dampak terhadap tahun berikutnya setelah Dana Desa diterima.

Hipotesis $\mathrm{H}_{2}$ pada penelitian ini adalah kualitas penyelenggaraan Pemerintahan Daerah memperkuat pengaruh positif Dana Desa terhadap Pendapatan Asli Daerah. Hipotesis $\mathrm{H}_{2}$ pada penelitian ini adalah kualitas penyelenggaraan Pemerintahan Daerah memperkuat pengaruh positif Dana Desa terhadap Pendapatan Asli Daerah. Pengujian hipotesis $\mathrm{H}_{2}$ dilakukan secara terpisah dari pengujian hipotesis $\mathrm{H}_{1}$ karena dilakukan untuk membuktikan pengaruh variabel moderasi EKPPD terhadap Dana Desa yang dituliskan dengan variabel (EKPPD x Dana Desa). Berdasarkan hasil pengujian hipotesis $\mathrm{H}_{2}$ yang ditunjukkan pada Tabel 6, variabel (EKPPD x Dana Desa) pada model 3 dan 4 menunjukkan nilai probabilitas sebesar 0,000 atau lebih kecil dari 0,05. Nilai koefisien yang menunjukkan hubungan variabel (EKPPD x Dana Desa) dengan variabel dependen pada kedua model juga bertanda positif. Temuan ini mengindikasikan bahwa EKPPD sebagai pemoderasi memperkuat pengaruh Dana Desa terhadap Pendapatan Asli Daerah sehingga dapat disimpulkan bahwa hipotesis $\mathrm{H}_{2}$ terbukti dan diterima.

Tabel 6

Hasil Pengujian Hipotesis $\mathrm{H}_{2}$

\begin{tabular}{|c|c|c|c|c|c|c|}
\hline \multirow{2}{*}{ Variabel } & \multicolumn{3}{|c|}{$\begin{array}{c}\text { Model } 3 \\
\text { Variabel Dependen: PAD }\end{array}$} & \multicolumn{3}{|c|}{$\begin{array}{c}\text { Model } 4 \\
\text { Variabel Dependen: PADlag }\end{array}$} \\
\hline & Coef. & t-stat & Prob. & Coef. & t-stat & Prob. \\
\hline DanaDesa & -214547 & -233 & 0,020 & $-853,8513$ & $-4,98$ & 0,000 \\
\hline EKPPD & $4,22 E+09$ & 0,65 & 0,514 & $-3,54 E+09$ &,- 029 & 0,769 \\
\hline EKPPD x DanaDesa & 1096217 & 3,61 & 0,000 & 401,6611 & 7,1 & 0,000 \\
\hline Penduduk & 320992,4 & 0,93 & 0,351 & 2906371 & 4,54 & 0,000 \\
\hline LuasWilayah & -219093 & -73 & 0,468 & -7146628 & $-0,95$ & 0,34 \\
\hline \multirow[t]{4}{*}{ Intersep } & $-2,75 E+10$ & -19 & 0,846 & $-1,07 \mathrm{E}+12$ & $-4,08$ & 0,000 \\
\hline & R squared & 0,7377 & & R squared & 0,7378 & \\
\hline & F-Stat & 25,49 & & F-Stat & 94,74 & \\
\hline & Prob $>F$ & 0,0000 & & Prob $>F$ & 0,0000 & \\
\hline
\end{tabular}

\section{KESIMPULAN DAN SARAN}

Penelitian ini bertujuan untuk meneliti pengaruh Dana Desa terhadap Pendapatan Asli Daerah dan pengaruh kualitas penyelenggaraan pemerintahan daerah dalam memperkuat pengaruh Dana Desa terhadap Pendapatan Asli Daerah di Indonesia. Penelitian ini dilakukan dengan dua model yaitu nonlagged panel regression model dan lagged panel regression model. Berdasarkan kedua model tersebut, penelitian ini berhasil menemukan hubungan positif dan signifikan Dana Desa terhadap Pendapatan Asli Daerah. Kualitas penyelenggaraan pemerintahan daerah juga memoderasi secara positif signifikan pengaruh Dana Desa terhadap Pendapatan Asli Daerah.

Berdasarkan temuan-temuan di atas dapat disimpulkan bahwa secara umum di Indonesia, Dana Desa yang diberikan oleh Pemerintah Pusat ke Desa dalam suatu wilayah kabupaten/kota memberikan pengaruh positif terhadap kemampuan daerah dalam menghasilkan Pendapatan Asli Daerah Kabupaten/Kota tersebut, baik pada tahun diberikannya Dana Desa maupun pada tahun setelah Dana Desa digulirkan. Pengaruh positif Dana Desa terhadap Pendapatan Asli Daerah ini diperkuat dengan tingkat kualitas penyelenggaraan pemerintahan daerah kabupaten/kota. Implikasi teoritis dari penelitian ini adalah pentingnya Dana Desa dan kualitas penyelenggaraan pemerintahan daerah yang baik bagi Daerah untuk meningkatkan kemampuan menghasilkan Pendapatan Asli Daerahnya sehingga mendorong kemandirian Daerah sebagai wujud keberhasilan kebijakan desentralisasi fiskal di Indonesia.

\section{IMPLIKASI DAN KETERBATASAN}

Penelitian ini memiliki keterbatasan pada periode tahun karena keterbatasan data yang tersedia. Penelitian selanjutnya disarankan untuk menambah periode tahun penelitian dan periode lag data untuk memperluas sampel penelitian. Selain itu, penelitian selanjutnya disarankan untuk menambah variabel independen dalam penelitian untuk menghasilkan model dan hasil penelitian yang lebih baik.

\section{DAFTAR PUSTAKA (REFERENCES)}

Azwardi, A., \& Sukanto, S. (2014). Efektifitas Alokasi Dana Desa (ADD) dan Kemiskinan di Provinsi Sumatera Selatan. Jurnal Ekonomi Pembangunan (Journal of Economics and Development), 12(1), 29-41.

Badan Pusat Statistik. (2015). Proyeksi Penduduk Kabupaten/Kota Provinsi Bali Tahun 2010-2020. Jakarta: Badan Pusat Statistik. 
Badan Pusat Statistik. (2015). Proyeksi Penduduk Kabupaten/Kota Provinsi Banten Tahun 20102020. Jakarta: Badan Pusat Statistik.

Badan Pusat Statistik. (2015). Proyeksi Penduduk Kabupaten/Kota Provinsi Bengkulu Tahun 20102020. Jakarta: Badan Pusat Statistik.

Badan Pusat Statistik. (2015). Proyeksi Penduduk Kabupaten/Kota Provinsi DI Yogyakarta Tahun 2010-2020. Jakarta: Badan Pusat Statistik.

Badan Pusat Statistik. (2015). Proyeksi Penduduk Kabupaten/Kota Provinsi DKI Jakarta Tahun 2010-2020. Jakarta: Badan Pusat Statistik.

Badan Pusat Statistik. (2015). Proyeksi Penduduk Kabupaten/Kota Provinsi Gorontalo Tahun 20102020. Jakarta: Badan Pusat Statistik.

Badan Pusat Statistik. (2015). Proyeksi Penduduk Kabupaten/Kota Provinsi Jawa Tengah Tahun 2010-2020. Jakarta: Badan Pusat Statistik.

Badan Pusat Statistik. (2015). Proyeksi Penduduk Kabupaten/Kota Provinsi Jawa Timur Tahun 2010-2020. Jakarta: Badan Pusat Statistik.

Badan Pusat Statistik. (2015). Proyeksi Penduduk Kabupaten/Kota Provinsi Kalimantan Barat Tahun 2010-2020. Jakarta: Badan Pusat Statistik.

Badan Pusat Statistik. (2015). Proyeksi Penduduk Kabupaten/Kota Provinsi Kalimantan Selatan Tahun 2010-2020. Jakarta: Badan Pusat Statistik.

Badan Pusat Statistik. (2015). Proyeksi Penduduk Kabupaten/Kota Provinsi Kalimantan Tengah Tahun 2010-2020. Jakarta: Badan Pusat Statistik.

Badan Pusat Statistik. (2015). Proyeksi Penduduk Kabupaten/Kota Provinsi Kalimantan Utara Tahun 2010-2020. Jakarta: Badan Pusat Statistik.

Badan Pusat Statistik. (2015). Proyeksi Penduduk Kabupaten/Kota Provinsi Kep. Bangka Belitung Tahun 2010-2020. Jakarta: Badan Pusat Statistik.

Badan Pusat Statistik. (2015). Proyeksi Penduduk Kabupaten/Kota Provinsi Lampung Tahun 20102020. Jakarta: Badan Pusat Statistik.

Badan Pusat Statistik. (2015). Proyeksi Penduduk Kabupaten/Kota Provinsi Maluku Tahun 20102020. Jakarta: Badan Pusat Statistik.

Badan Pusat Statistik. (2015). Proyeksi Penduduk Kabupaten/Kota Provinsi Maluku Utara Tahun 2010-2020. Jakarta: Badan Pusat Statistik.

Badan Pusat Statistik. (2015). Proyeksi Penduduk Kabupaten/Kota Provinsi Nusa Tenggara Barat Tahun 2010-2020. Jakarta: Badan Pusat Statistik.

Badan Pusat Statistik. (2015). Proyeksi Penduduk Kabupaten/Kota Provinsi Nusa Tenggara Timur Tahun 2010-2020. Jakarta: Badan Pusat Statistik.

Badan Pusat Statistik. (2015). Proyeksi Penduduk Kabupaten/Kota Provinsi Papua Barat Tahun 2010-2020. Jakarta: Badan Pusat Statistik.

Badan Pusat Statistik. (2015). Proyeksi Penduduk Kabupaten/Kota Provinsi Papua Tahun 20102020. Jakarta: Badan Pusat Statistik.
Badan Pusat Statistik. (2015). Proyeksi Penduduk Kabupaten/Kota Provinsi Sulawesi Barat Tahun 2010-2020. Jakarta: Badan Pusat Statistik.

Badan Pusat Statistik. (2015). Proyeksi Penduduk Kabupaten/Kota Provinsi Sulawesi Selatan Tahun 2010-2020. Jakarta: Badan Pusat Statistik.

Badan Pusat Statistik. (2015). Proyeksi Penduduk Kabupaten/Kota Provinsi Sulawesi Tengah Tahun 2010-2020. Jakarta: Badan Pusat Statistik.

Badan Pusat Statistik. (2015). Proyeksi Penduduk Kabupaten/Kota Provinsi Sulawesi Tenggara Tahun 2010-2020. Jakarta: Badan Pusat Statistik.

Badan Pusat Statistik. (2015). Proyeksi Penduduk Kabupaten/Kota Provinsi Sulawesi Utara Tahun 2010-2020. Jakarta: Badan Pusat Statistik.

Badan Pusat Statistik. (2015). Proyeksi Penduduk Kabupaten/Kota Provinsi Sumatera Utara Tahun 2010-2020. Jakarta: Badan Pusat Statistik.

Badan Pusat Statistik Provinsi Aceh. (2018). Proyeksi Penduduk Kabupaten/Kota Provinsi Aceh Tahun 2015-2025. Banda Aceh: Badan Pusat Statistik Provinsi Aceh.

Badan Pusat Statistik Provinsi Jambi. (2018). Proyeksi Penduduk Kabupaten/Kota Provinsi Jambi Tahun 2015-2025. Jambi: Badan Pusat Statistik Provinsi Jambi.

Badan Pusat Statistik Provinsi Jawa Barat. (2019). Proyeksi Penduduk Kabupaten/Kota Provinsi Jawa Barat Tahun 2015-2025 Hasil Supas 2015. Bandung: Badan Pusat Statistik Provinsi Jawa Barat.

Badan Pusat Statistik Provinsi Kalimantan Timur. (2018). Proyeksi Penduduk Kabupaten/Kota Provinsi Kalimantan Timur Tahun 2015-2025. Samarinda: Badan Pusat Statistik Provinsi Kalimantan Timur.

Badan Pusat Statistik Provinsi Kepulauan Riau. (2017). Proyeksi Penduduk Kabupaten/Kota Provinsi Kepulauan Riau 2015-2025. Tanjungpinang: Badan Pusat Statistik Provinsi Kepulauan Riau.

Badan Pusat Statistik Provinsi Lampung. (2014). Proyeksi Penduduk Lampung (2010-2035) dan Kabupaten/Kota (2010-2020). Bandar Lampung: Badan Pusat Statistik Provinsi Lampung.

Badan Pusat Statistik Provinsi Riau. (2018). Proyeksi Penduduk Kabupaten/Kota Provinsi Riau 20152025. Pekanbaru: Badan Pusat Statistik Provinsi Riau.

Badan Pusat Statistik Provinsi Sumatera Barat. (2018). Proyeksi Penduduk Kabupaten/Kota Provinsi Sumatera Barat 2015-2025 Hasil Supas 2015. Padang: Badan Pusat Statistik Provinsi Sumatera Barat.

Badan Pusat Statistik Provinsi Sumatera Selatan. (2017). Proyeksi Penduduk Kabupaten/Kota Provinsi Sumatera Selatan 2015-2025. 
Palembang: Badan Pusat Statistik Provinsi Sumatera Selatan.

Direktorat Jenderal Perimbangan Keuangan. (2017). Ringkasan Realisasi APBD tahun 2015 per 4 Juli 2017 (file excel). Diakses dari http://www.djpk.kemenkeu.go.id/?p=5412

Direktorat Jenderal Perimbangan Keuangan. (2018). Ringkasan Realisasi APBD tahun 2016 per 11 Oktober 2018 (file excel). Diakses dari http://www.djpk.kemenkeu.go.id/?p=5412

Direktorat Jenderal Perimbangan Keuangan. (2018). Ringkasan Realisasi APBD tahun 2017 per 12 November 2018 (file excel). Diakses dari http://www.djpk.kemenkeu.go.id/?p=5412

Cooray, A. V. (2009). Government Expenditure, Governance and Economic Growth. Comparative Economic Studies, Vol. 51 (3), hal. 401-418.

Friedmann, J. 1992. Empowerment: The Politics of an Alternative Development. Oxford: Basil Blackwell.

Hamid, K.T. (2013). Good Governance and New Public Sector Financial Management Reform in Nigeria. Being a Paper Presented at the Executive Mandatory Professional Training Programme for Fellows of the Chartered Institute of Finance and Control of Nigeria (CIFCN), with the Theme "New Public Sector Financial Management Reform: A Panacea or Placebo for Transparency and Accountability in Nigeria", Held at Grand Ibro Hotel, Plot 1960, Michael Okpara Street, By Civil Defence Headquarters, Wuse Zone 5, Abuja-FCT on 15th and 16th June, 2013.

Hariyanto, S., \& Mutiarin, D. (2016). Dampak Kebijakan Alokasi Dana Desa (ADD) Terhadap Pembangunan Desa di Kabupaten Bulungan Tahun 2011-2014. Journal of Governance and Public Policy, 2(3).

Keputusan Menteri Dalam Negeri Nomor 120 - 10421 Tahun 2016 tentang Penetapan Peringkat dan Status Kinerja Penyelenggaraan Pemerintahan Daerah Secara Nasional Tahun 2015.

Keputusan Menteri Dalam Negeri Nomor 100 - 53 Tahun 2018 tentang Peringkat dan Status Kinerja Penyelenggaraan Pemerintahan Daerah Secara Nasional.

Kuang, Tan Ming. (2019). Pemetaan Masalah dan Potensi BUM Desa Sukajadi di Kabupaten Garut, Jawa Barat. Prosiding Seminar Nasional Hasil Pengabdian kepada Masyarakat Vol. 4, No. 1.

Marx, C. (1969). Theories of Surplus Value, Volume 1. California: Lawrence \& Wishart.

Masaki, T. (2018). The Impact of Intergovernmental Transfers on Local Revenue Generation in SubSaharan Africa: Evidence from Tanzania. World Development, 106, 173-186.
Peraturan Menteri Dalam Negeri Nomor 137 Tahun 2017 tentang Kode dan Data Wilayah Administrasi Pemerintahan

Peraturan Pemerintah Republik Indonesia Nomor 6 Tahun 2008 tentang Pedoman Evaluasi Penyelenggaraan Pemerintahan Daerah

Peraturan Pemerintah Republik Indonesia Nomor 60 Tahun 2014 tentang Dana Desa yang Bersumber dari Anggaran Pendapatan dan Belanja Negara

Peraturan Presiden Republik Indonesia Nomor 162 Tahun 2014 tentang Rincian Anggaran Pendapatan dan Belanja Negara Tahun Anggaran 2015

Peraturan Presiden Republik Indonesia Nomor 137 Tahun 2015 tentang Rincian Anggaran Pendapatan dan Belanja Negara Tahun Anggaran 2016

Peraturan Presiden Republik Indonesia Nomor 97 Tahun 2016 tentang Rincian Anggaran Pendapatan dan Belanja Negara Tahun Anggaran 2017

Sasana, H. (2009). Peran Desentralisasi Fiskal terhadap Kinerja Ekonomi di Kabupaten/Kota Provinsi Jawa Tengah. Jurnal Ekonomi Pembangunan, Vol. 10, No.1, Juni 2009, hal. 103 - 124.

Sekaran U., \& Bougie R. (2017). Metode Penelitian untuk Bisnis: Pendekatan PengembanganKeahlian Edisi 6 Buku 1. Jakarta: Salemba Empat.

Sumaryana, A., Rusli, B., \& Buchari, R. A. (2018). Analisis Dampak Pengelolaan dan Penggunaan Dana Desa terhadap Pembangunan Daerah. Jurnal Ilmu Pemerintahan dan Sosial Politik UMA, 6 (1), 14-24.

Titman, S., Keown, A.J., \& Martin, J.D. (2014). Financial Management: Principles and Applications Twelfth Edition. New Jersey: Pearson Education, Inc.

Undang-Undang Republik Indonesia Nomor 33 Tahun 2004 tentang Perimbangan Keuangan Antara Pusat dan Daerah

Undang-Undang Republik Indonesia Nomor 6 Tahun 2014 tentang Desa

Undang-Undang Republik Indonesia Nomor 23 Tahun 2014 tentang Pemerintahan Daerah 